\title{
Digital technologies in the tax sphere as a factor in the sustainability of economic activity
}

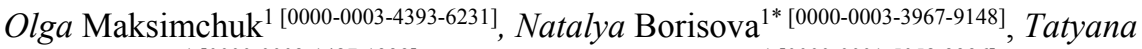 \\ Ereshchenko ${ }^{1 \text { [0000-0002-1487-1339], and Vladislav Klyushin }{ }^{10000-0001-5058-3396] ~}}$ \\ ${ }^{1}$ Volgograd State Technical University, 400074, Lenin avenue, Volgograd, Russia
}

\begin{abstract}
In the future, digital technologies will make it possible to increase the transparency of the economic activities of tax organizations, the transparency of the economy of all economic entities in Russian Federation, which guarantees the stability of receipts to the country's budget, an improvement in the quality of budget planning and economic stability. The purpose of this study is to substantiate the optimization of the economic activities of tax organizations based on the introduction of digital technologies. The object of the research is the economic activity of tax organizations. The subject of the research is digital technologies as a factor in optimizing economic activity and the sustainability of tax organizations. The analysis of the efficiency of tax organizations is presented. The author's vision of the influence of digital technologies on the optimization of economic activity is given on the example of the branch of the Federal Tax Service of the Russian Federation in terms of tax control and the provision of public services. It is concluded that the optimization of the economic activities of tax organizations based on the introduction of digital technologies will reduce the costs of current activities, tax administration, time costs for tax transactions.
\end{abstract}

Keywords: digital technologies, factor, optimization, sustainability, economic activity, tax organizations, digital economy.

\section{Introduction}

Currently, the digital economy is included in the global economy with a new stage in the technology race. There is no doubt that states which create a favorable environment for the development and replication of digital technologies will determine the pace in the global market. Digital technologies have united all structures of life, transformed economic and organizational operations, ways of communication between suppliers and consumers of goods and services. At present, Russia takes the 38th place, behind Finland, Switzerland, Sweden, Israel, Singapore and other countries $[1,2]$, in terms of the development of digital technologies, but, unfortunately, in various ratings Russia's positions are not leadership in terms of the level of digital technologies [3]:

- 26th place out of 49 (Bloomberg Innovation Index 2020);

- 23rd place out of 24 (Digital Society Index 2019);

* Corresponding author: borisovani06@mail.ru 
- fulfilment of 28 points out of 50 maximum for the given period (Index of Business Digitalization by the Institute for Statistical Studies and Economics of Knowledge of the National Research University Higher School of Economics for 2019);

- 40th position out of 63 (IMD World Digital Competitiveness Ranking 2019);

- 7.07 points out of 10 (ICT Development Index (IDI) 2017 г.);

- 38th place out of 193 (Global Competitiveness Report 2017);

- 28th place out of 139 (Global Cybersecurity Index 2017).

The digital economy is no longer a trend for the future; it is the present, which dictates its principles and rules to all economic entities and state institutions. It concerns to the tax institution. Tax organizations were one of the first organizations which started to use information and communication resources in their economic activities, especially it concerns performing the functions of tax accounting and control over the economic activities of individuals and legal entities, and the provision of public services. Digitalization in the tax sphere began in the $90 \mathrm{~s}$, when automated systems were introduced and tax inspectors worked only with typewriters. The fundamental change in «production chains», the speed of data transfer, the growth of electronic transactions and operations related to tax accounting and control directly depend on the level of development and the degree of implementation of digital technologies. From this point of view, digital technologies are a resource of trust that allows using IT technologies to ensure voluntary compliance with tax legislation by taxpayers, that is, to be «transparent» in the digital space. The more «transparent» the digital features of an economic entity, the more reliable its position as a business partner. This is confirmed by the data of such portals as:

- Verification and analysis of Russian legal entities: https://www.rusprofile.ru/;

- Accounting, taxation, audit in the Russian Federation: https://www.audit-it.ru/;

- All-Russian system of data on companies and business: https://zachestnyibiznes.ru/ and others.

In the future, digital technologies will allow to increase the transparency of the economy for all constituent entities of the Russian Federation, improve the quality of budget planning and guarantee the stability of revenues to the country's budget $[4,5]$. The internal organizational activity of business entities should also be more effective. We expect to build external «production chains» and also to optimize internal processes and operations from the introduction of digital technologies.

\section{Materials and methods}

Tax organizations are no exception. Thus, the introduction of digital technologies in tax organizations (using the example of the Federal Tax Service - hereinafter FTS) promotes transparency and trust in interaction with taxpayers. Almost all taxpayer data is provided in obligatory reporting - under the guarantee of protecting this information from leaks. It is subject to regulatory and legal compliance. In fact, the control and supervisory activities of tax organizations are focused on identifying potential violations. It is very routine, burdensome operations in terms of the amount of information, calculated data, they are expensive due to time, labor and financial resources.

Due to the active use of digital technologies by tax organizations in optimizing economic activities, over the past 10 years, the number of on-site inspections has decreased from 87.9 thousand units up to 10.9 thousand units. Now the FTS checks only two taxpayers out of 1000. At the same time, receipts from one check are growing and are on average, 22.3 million rubles. Tax organizations become participants to arbitration cases less and less often - in recent years, the number of disputes with tax organizations has decreased by $13.8 \%$. 
According to the final report on the work of the service for $2019,85.4 \%$ cases of the total number of claims considered by courts of various levels in all disputes with taxpayers, were resolved in favor of the tax authorities, in 2018 and $2017-82.6 \%$ and $80.3 \%$ respectively [6].

On February 21, 2020, it became known about the FTS's introduction of an electronic wallet to pay tax debts by companies by. The system of a single tax payment for individual entrepreneurs and companies allows to remotely receive information about the presence of tax arrears, to exclude the blocking of accounts by quickly paying for the arisen debt. The tasks of collecting more taxes, searching for additional charges, which led to deformation of the economic activity of tax authorities and the impossibility of developing improved services with self-payment of charges, remained in the past.

In December 2019, the Government of the Russian Federation submitted for ratification a protocol for the electronic exchange of tax data with the CIS countries. This document presents the exchange of information about the income of companies and individuals that were received in another state, as well as about their vehicles and real estate located abroad. Electronic exchange of information on tax issues will undoubtedly become an additional tool for countering illegal concealment of capital abroad, reducing the shadow economy and resisting tax evasion. The exchange of data between the tax authorities of the CIS countries will be carried out in electronic form through open communication channels using the cryptographic information protection tool «Krypton-Ankad», which will provide the information exchange security.

Since the end of 2019, the FTS of Russia has been exchanging information automatically on financial accounts with more than 70 jurisdictions. The reports include the name, account number, balance, investment income, percentages on deposits and bonds, data on the movement of funds for the year, profit from the share sale. Comparison of the data of this system with the data of the taxpayer in the declaration allows to identify tax violations. Auto-exchange is the main driver of deoffshorization along with the tightening of transparency requirements in low-tax jurisdictions. Undoubtedly, investments contribute to the development of economic activity in the countries where they are directed, primarily in developing countries and countries with transition economy. In addition, they ensure the introduction of new, advanced technologies, thereby increasing labor productivity, expanding exports, stimulating economic growth and increasing employment [7].

Another important achievement in optimizing the economic activities of tax authorities is the exchange of the FTS with the customs service and the risk management system, which allows coordinated activities of organizations. The customs authorities carry out information and law enforcement functions, which consist in providing customs data to the country's leadership and in resisting violations of customs rules and crimes in the field of customs. Thus, the customs service prevents all factors that have a negative impact from the outside, both on foreign economic activity and on the level of economic security of the state. The FTS and customs have been provided with the same profiles of taxpayers, it allows to understand what questions another service may have to this person $[8,9]$.

The widespread introduction of big data technology has made it possible to significantly change the procedure for conducting desk audits of the payment of value added tax (hereinafter - VAT), minimizing the influence of the human factor. The current ASK VAT2 system made it possible to quickly and reliably analyze the chains of added value forming and automatically suppress not only VAT evasion, but also attempts at fraud in VAT refunds. The technological capabilities of the ASK VAT-2 system allow to significantly simplify the procedure for controlling VAT declarations and automate the process of analyzing transactions with counterparties in order to identify discrepancies.

The share of doubtful deductions declared by unscrupulous taxpayers in the 3 rd quarter of 2019 decreased to $0.7 \%$ - more than 13 times, while the 3rd quarter of 2017 it was $9 \%$. 
According to data [10], the share of dubious VAT transactions at the beginning of 2021 is $0.43 \%$ compared to $8 \%$ in 2016 . AIS tax processes 15 billion invoices per year, cash registers daily knock out 170 million checks, which online through specialized operators are transferred to the FTS. Only 1.3 million people pay professional income tax.

These indicators are due to the successful operation of the ASK VAT-2 system. During the period of the ASK VAT-2 system activity in 2019, the average Russian tax gap for VAT decreased from $8 \%$ at the beginning of 2017 to $1 \%$. In 2019, the FTS of Russia reduced the term for a desk tax audit of the declaration from three months to two. Since then, it has become possible to get a VAT refund faster. The number of fly-by-night companies in Russia is decreasing to 500 thousand a year. Moreover, a traceability system (production and turnover control system) was tested and implemented, which led to a significant reduction in the share of the shadow sector in certain markets. In turn, the shadow sector of the economy includes the activities of criminal structures, which poses a threat not only to state security, but also to the life of citizens. As noted by Yu. P. Kulik, «the main negative consequence of the shadow economy is the deformation of the economy structure, which manifests itself in an increase in investment risks and a reduction in investment». A serious problem to state security is the so-called informal employment, accompanied by evasion of taxes and contributions to insurance funds, as well as the economic activity of criminal organizations, state and municipal enterprises. Therefore, the use of digital technologies plays an important role in optimizing the activities of tax organizations $[6,8]$.

\section{Results and discussion}

A significant impact on the increase in tax revenues to the budget is also exerted by the use of a new technology for transmitting information to the tax authorities using a new cash register equipment - online cash registers. The introduction of this technology allowed the tax authorities to quickly receive and analyze all sales data, which significantly improved control over one of the most difficult administer sectors of the economy - retail trade. After the introduction of this system, the average revenue for each cash register became 1.5 times higher than before the reform.

It makes it possible to control the amount of funds in retail in the amount of 2.5 trillion per month. With the introduction of online cash registers in our country, the unified system was created in which the data of all receipts for the sale of goods automatically go to the tax service. The transparency of relations with taxpayers is becoming an important component.

In 2020, one of the projects of new digital services for the development of a certification center (CA) was launched, providing qualified electronic signature certificates for legal entities, notaries and individual entrepreneurs. It is expected that in 2021, the CA will receive $35 \%$ of the total number of those who in need of such services, and in 2022 , the CA will process $100 \%$ of requests [11].

On August 20, 2020 it became known that the FTS will receive online access to the accounting and tax reporting of companies representing medium-sized businesses. The Ministry of Finance of the Russian Federation will expand the number of companies connected to the tax monitoring system by including remote access to accounting and tax reporting not only of the largest companies, but also of those whose annual revenues and assets do not exceed 1 billion rubles, and the amount of taxes is up to 100 million rubles. Organizations voluntarily provide access to their data and, if there are risks of violations of the law, the tax service recommends eliminating them. Businesses will only be fined for criminal violations. Thus, the system will reduce and greatly simplify document flow. The FTS will not be able to check millions of transactions, but only track certain high-risk transactions. 
Due to the efficient administration of insurance premiums by the tax authorities in 2017 , 5.8 trillion rubles were received in extra-budgetary funds, which is $9.1 \%$ (483 billion rubles) more than in 2016, including 4.5 trillion rubles to the Pension Fund budget, which is $8.7 \%$, or almost 360 billion rubles more than in 2016. In addition, the revised PFR budget received 42 billion rubles, the MHIF budget -27 billion rubles. Along with it, the growth rate of insurance premium receipts by $1.9 \%$ exceeded the growth rate of average monthly wages $(107.2 \%)$. So, revenues that have been received in excess of the established budget indicators will help reduce the burden on the federal budget in terms of allocating a transfer to cover the budget deficit of the Funds, thereby increasing the efficiency of economic activities of tax organizations $[11,12]$.

In addition, the FTS of Russia has carried out colossal work to settle insurance premiums arrears. There have been settled more than 173 billion rubles of the 522 billion rubles in arrears received from state extra-budgetary funds on January 1, 2017. The largest part was formed by the accumulated debt of individual entrepreneurs, calculated on the basis of eight times the minimum wage in case of failure to submit reports - 111 billion rubles at the beginning of 2018. This debt cannot be collected in full due to the actual lack of income or the termination of entrepreneurial activities by taxpayers without de-taxation. In order to avoid social tension, the country's leadership decided to write it off (Federal Law of December 28, 2017 No. 436-FZ) without the participation of taxpayers, according to the funds.

5.5 million legal entities and individual entrepreneurs (more than $60 \%$ ) of 8.2 million, use special tax regimes and are related to small businesses. This category of taxpayers that most noticeably feels the decrease in administrative pressure - in 2019, one taxpayer out of 4000 was checked. This is $0.025 \%[13,14,15]$.

Since 2019, a more advanced automated information system «Tax-3» (AIS Tax-3) has appeared. The main functions of AIS Tax-3 are: administration of VAT, registration of individuals and legal entities, administration of individual taxes, accounting of cash registers. AIS Tax-3 is a database of all taxpayers. The inspectors working in the system are getting more and more opportunities to control the movement of funds between the accounts of legal entities and individuals. Most of the transactions can be seen in real time. In this regard, it has become problematic for unscrupulous taxpayers to apply shadow schemes in their business activities.

The economic activity of the tax authorities has been qualitatively improved in terms of the administration of property taxes. Recently, automated systems for centralized settlement have been introduced, which contain more than 109 million different tax liabilities. It allowed tax organizations to combine accruals for all assets in one tax notice.

The FTS websites currently have 50 electronic services. A taxpayer can receive a full range of services, from registering his business to paying taxes to the budget. The procedure for deducting personal income tax has become simplified due to the introduction of the personal taxpayer account. Russians can download the certificate of 2-personal income tax to their computer in the form of files in .pdf and .xml formats, signed with a qualified signature of the FTS. Although previously it was only possible to view a certificate of income. The most demanded service of this department is the provision of declarations: in the FTS 17 consumed services of 47 are the submission of declarations. The share of taxpayers - organizations conducting financial and economic activities and submitting tax returns via telecommunications channels in the Internet, amounted to 96.03 $\%$ [16].

Digitalization of tax administration, accounting and control allows not only to optimize the economic activities of tax organizations, significantly reducing resource costs, but also in general to bring the economy to a new level, to make monitoring of the tax burden of business entities more efficient, thereby reducing tax risks, and also leads to a reduction in 
the number of on-site tax audits, an increase in the economic activity of tax organizations in general. At the same time, according to the official data of the FTS, the collection of taxes and fees in 2020 was $98.72 \%$, in $2019-98.65 \%$. But the level of satisfaction of citizens with the quality of public services has reached more than $90.0 \%$ and is a constant indicator for last two years.

Over the past few years, the FTS of Russia has made a significant qualitative breakthrough in terms of the development of digital information technologies, which have significantly increased the growth of tax revenues to the budget. All tax revenues administered by the FTS of Russia are growing at a higher rate, exceeding the rate of growth of the economy and GDP. In 2020, the FTS was able to provide the highest growth in tax revenues to the country's budget in the last five years - more than 5532.2 billion rubles, that is 308.3 billion rubles more than in 2019 (Table) [16, 17].

The final sentence of a caption must end with a period.

Table. Revenues by budget levels for the 1st quarter of 2019-2020 [18, 19].

\begin{tabular}{|l|c|c|c|}
\hline \multirow{2}{*}{\multicolumn{1}{|c|}{ Budget type }} & \multicolumn{3}{c|}{ 1st quarter, billion rubles } \\
\cline { 2 - 4 } & 2019 & 2020 & Growth rate \% \\
\hline $\begin{array}{l}\text { Consolidated budget } \\
\text { of the Russian } \\
\text { Federation }\end{array}$ & 5223.9 & 5532.2 & 105.9 \\
\hline Federal budget & 3026.9 & 3153.1 & 104.2 \\
\hline $\begin{array}{l}\text { Consolidated } \\
\text { budgets of the } \\
\text { Russian Federation } \\
\text { subjects }\end{array}$ & 2197 & 2379.1 & 108.3 \\
\hline
\end{tabular}

The largest share of revenues was property taxes, which increased by $33 \%$ in 2020 compared to 2019, there was a significant increase in personal income tax revenues - by $12.0 \%$, income tax $-5.9 \%$, and VAT revenues increased by $5.1 \%$ (Fig.). Such dynamics presents the effective use of digital technologies in optimizing the economic activities of tax organizations [20-32].

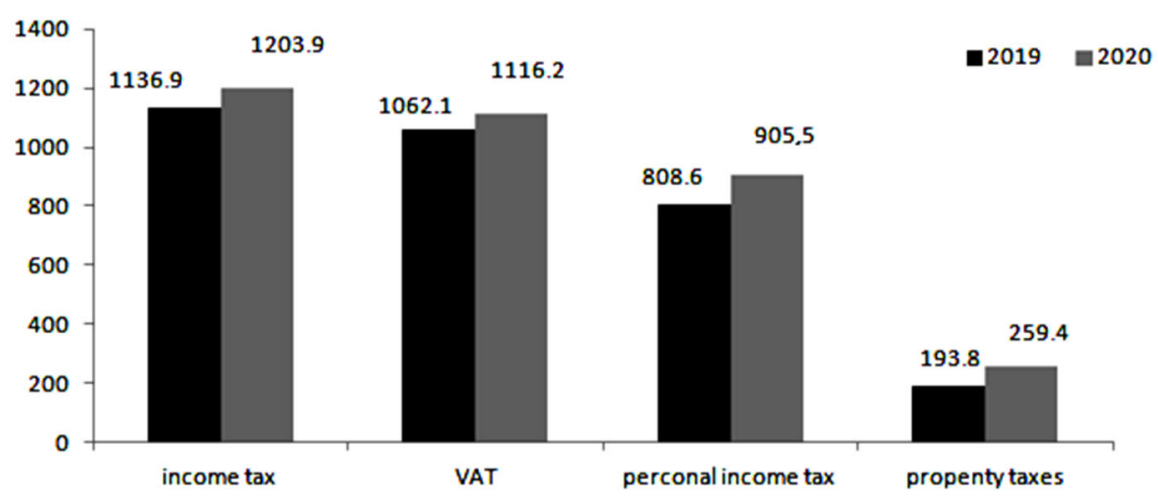

Fig. Tax receipts to the consolidated budget of the Russian Federation for the 1st quarter of 20192020 , billion rubles [18]. 
In addition, the economic activity of the tax authorities was qualitatively improved in terms of the administration of property taxes. Recently, automated systems have been introduced for more than 109 million different tax liabilities for their centralized calculation, that allowed the tax authorities to combine charges for all property objects in one tax notification.

A negative point in optimizing the economic activities of tax organizations based on the introduction of digital technologies is that the number of these organizations has significantly decreased over the past 10 years, many departments conducting tax audits have been closed and, as a result, there are large redundancies in specialists. But this is an inevitable phenomenon of any digitalization, when any organization must provide professional retraining of the released specialists, or expand its activities based on the development of new digital resources. Automation and robotization, which are accompanied by a radical renewal of fixed assets, will lead to a decrease in the contribution of such a factor of production as labor to economic growth, with a consistent increase in the contribution of capital in almost all sectors of the economy. The formation of digital infrastructure, first of all, can contribute to an increase in the growth rates of the financial, transport and construction sectors. In addition, digital technologies will improve the quality of services and accessibility in the social sphere, education, healthcare, financial sector, housing and communal services $[18,19]$.

By the decision of the Presidium of the Government Commission on Digital Development, the Use of Information Technologies to Improve the Quality of Life and Conditions for Doing Business (the Protocol of December 25, 2020 No. 34), the Concept for the Development of Electronic Document Management in Economic Activity was approved. Based on the Order of the FTS of Russia dated 03.11.2020 N ED-7-17/788@, (registered with the Ministry of Justice of Russia 09.12.2020 N 61363), auto-exchange of information on financial accounts (CRS) in 2021 will be carried out with 79 countries and 12 territories [20-25].

Digital technologies in the tax area within the framework of the implementation of this Concept will provide:

- transfer to electronic form $95 \%$ of invoices issued by business entities, with the exception of invoices, for which a different exchange procedure is provided in connection with their classification as state secrets - by the end of 2024 ;

- transfer of $70 \%$ of transport and consignment notes generated by business entities into electronic form, with the exception of documents for which a different exchange procedure is provided in connection with their classification as a state secret - by the end of 2024;

- an annual increase of at least $20 \%$ in the total number of electronic documents sent by business entities to each other in electronic form - starting from 2022;

- an annual decrease by at least $10 \%$ in the number of paper documents required under tax control measures - starting from 2023;

- reducing the costs of business entities for processing and storing paper documents following the results of the implementation of electronic document flow;

- increasing the transparency of transactions carried out by business entities;

transition to the use of information and records in the information system of state authorities instead of documents submitted by economic entities [26].

\section{Conclusions}

Modern digital technologies for managing information databases with a large amount of data, with a centralized information system and built-in analytical tools, make it possible to highlight a number of different advantages, both for each participant in tax legal relations, 
and for the entire Russian economy as a whole. For tax organizations, this is an opportunity to optimize economic activity by building effective external «production chains» with taxpayers and internal processes and operations. For business entities - service anywhere in the country from any device, minimum administrative burden and maximum comfortable conditions for effective work. For the national economy as a whole, this is a significant reduction in the size of the «shadow» sector and the creation of a healthy competitive environment. All these activities are currently being implemented by the FTS due to the introduction and widespread use of modern digital technologies.

Optimization of the economic activities of tax organizations in the context of digitalization leads to a steady increase in tax revenues to the budget, impressing with new information technologies and legal tools of tax administration. Changes in the rules for applying popular tax regimes, tightening tax administration, strengthening banking and interdepartmental control of financial and business transactions play an important role in creating a reliable basis for optimizing the economic activities of tax organizations based on digital technologies.

\section{References}

1. I. Smirnova, Mathematical models as the basis for the use of digital technologies at enterprises, Actual problems of economics and management, 4(24), 135-144 (2019)

2. O. Mikhaleva, D. Syradoev, T. Terekhova, Big data technology application in the taxation sphere, Lecture Notes in Networks and Systems, 139, 431-436 (2021).

3. Russia in IT-ratings. URL: https://www.tadviser.ru/index.php (last accessed: 25.01.2021).

4. N. Borovskikh, E. Kipervar, The development of electronic personnel document management of enterprises in the conditions of digitalization, Proceedings of the 1st International Scientific Conference MTDE, 81, 181-185 (2019) DOI: 10.2991/mtde19.2019.35

5. A. U. Mentsiev, M. S-U. Khaliev, E. Guzueva, A. Mentsiev, M. Ashakhanova, Digitalization as a New Stage in the Formation of Economic Relations, ISCFEC, 128, 3096-3100 (2020) DOI: 10.2991/aebmr.k.200312.443

6. D. Golovenkin, S. Lomonosov, Shadow economy and economic security - causation and interaction features, Actual problems of economics and management, 1(21), 12-16 (2019)

7. E. Smirnova, Tax control in the digital economy, Finance, 11, 32-34 (2017)

8. E. Polyakova, The concept and consequences of financial globalization, Actual problems of economics and management, 1(13), 55-59 (2017)

9. E. Shagiakhmetova, Yu. Medyanik, L. Gimadieva, D. Vakhitova, L. Yarullina. Economic efficiency of plastic recycling plant construction, IOP conference series materials science and engineering, 890, 012114 (2020) DOI: 10.1088/1757899 X/890/1/012194

10. Globalization. The Economist. URL: http://www.economist.com/node/14031230 (last accessed: 25.01.2021)

11. E. Oskina, O. Sysoeva, Influence of the activities of customs authorities on the country's economy, Actual problems of economics and management, 2(26), 95-102 (2020).

12. N. Yushchenko, E. Gumerova, Regulation of Digital Platforms in Russia: A Glimpse into the Future, 2nd International Scientific and Practical Conference MTDE, 138, 960-965 (2020) DOI: 10.2991/aebmr.k.200502.158 
13. E. Nesterenko, To the question of the importance of digitalization in the transformation of the state economy. Actual problems of economics and management, 2(26), 85-94 (2020).

14. M. Dubovik, Strategic Goals of the Region in the Context of Development of Digital Environment, ISCFEC, 128, 140-148 (2020) DOI: 10.2991/aebmr.k.200312.425

15. N. Victorova, E. Vylkova, N. Pokrovskaia, F. Shukhov, Information Technology and Innovation in Taxpayer Registration and Numbering: National and International Experience. ACM International Conference Proceeding Series, article 3373349 (2019)

16. Information technology in the Federal Tax Service. URL: https://www.tadviser.ru/index.php (last accessed: 25.01.2021)

17. M. Savchenko, O. Maksimchuk, Application of digital technologies as a factor of optimization of economic activity of tax organizations, Actual problems of economics and management, 4(28), 146-154 (2020).

18. Tax analytics. URL: https://analytic.nalog.ru/portal/index.ru-RU.htm (last accessed: 25.01.2021)

19. I. Tronina, G. Tatenko, S. Bakhtina, Digital technologies in solving problems of innovative development of Russian regions, Proceedings of the 1 st International Scientific Conference MTDE, 81, 253-261 (2019) DOI: 10.2991/mtde-19.2019.49

20. S. Grachev, O. Donichev, Digital technologies as regions innovative development factor, in Proceedings of the 1st International Scientific Conference MTDE, 81, 145149 (2019) DOI: 10.2991/mtde-19.2019.27

21. L. Gurieva, A. Borodin, A. Berkaeva, Management model transformation in the digital economy, in Proceedings of the 1st International Scientific Conference MTDE, 81, 383-387 (2019) DOI: 10.2991/mtde-19.2019.73

22. V. Koretskaia-Garmash, Digital economy and labour taxation: International and Russian policies on taxing freelancers, in Proceedings of the 33rd International Business Information Management Association Conference, IBIMA 2019: Education Excellence and Innovation Management through Vision 2020, 1492-1504 (2019)

23. L. Bryantseva, N. Shishkina, A. Tolstykh and O. Ukhina, Optimization of taxation for business entities under the conditions of regional sustainable development, IOP Conference Series: Materials Science and Engineering, 890, 0121921 (2020) DOI: 10.1088/1757-899X/890/1/012192

24. E. Okolelova, M. Shibaeva, L. Shulgina, A. Efimyev, N. Serebryakova, The model of forming of innovative financing and credit schemes in housing construction and estimation of their financial stability, IOP Conference Series: Materials Science and Engineering, 890, 012194 (2020) DOI: 10.1088/1757-899X/890/1/012194

25. A. Lutsenko, M. Vykluk, M. Skoryk, T. Hromova, Fiscal regulation concept formation of the Ukraine's economy development. Estudios de Economia Aplicada, 38 (4) (2020)

26. V. Zharov, Digitalization of the technological development management process of the Russian economy, in Proceedings of the 1st International Scientific Conference MTDE, 81, 273-276 (2019) DOI: 10.2991/mtde-19.2019.52

27. Yu. Dolganova, N. Istomina, M. Terentieva, Approaches to the regulation of the development of digitalization of finance in the regional economy. Proceedings of the 1st International Scientific Conference MTDE, 81, 268-271 (2019) DOI: $10.2991 / \mathrm{mtde}-19.2019 .51$

28. C. Isakov, Development of the Management and Incentive System for Innovation Activity of Enterprises in the Digital Economy, 2nd International Scientific and Practical Conference MTDE, 138, 1293-1298 (2020) DOI: 10.2991/aebmr.k.200502.215 
29. S. Ilyashenko, M. Belyakova, A. Zvereva, Possibilities of application of digital tools by the organizations of sphere of services and trade in the Russian Federation. IOP Conference Series: Materials Science and Engineering, 940 (1), article 012059 (2020)

30. M. Veselovsky, T. Pogodina, R. Ilyukhina, T. Sigunova, N. Kuzovleva, Financial and economic mechanisms of promoting innovative activity in the context of the digital economy formation. Entrepreneurship and Sustainability, 5(3), 672-681 (2018)

31. K. Nosalska, Z. M. Piątek, G. Mazurek, R. Rządca, Industry 4.0: coherent definition framework with technological and organizational interdependencies, Journal of Manufacturing Technology Management, 31(5), 837-862 (2019)

32. S. Sharmila, Digital finance with respect to financial inclusion. International, Journal of Recent Technology and Engineering, 8(3), 6321-6326 (2019) 